\title{
SUSTAINABILITY OF TRANSMIGRANT FARMERS' FARMING IN THE REGENCIES OF BANYUASIN AND OGAN ILIR, SOUTH SUMATERA PROVINCE
}

\author{
Malta \\ Lecturer of Universitas Terbuka, Jl. Cabe Raya, \\ Pondok Cabe - Tangerang Selatan, Indonesia
}

DOI: 10.46609/IJSSER.2020.v05i01.007 URL: https://doi.org/10.46609/IJSSER.2020.v05i01.007

\begin{abstract}
Sustainable transmigration development is in line with the concept of sustainable agricultural development. Agricultural development must be able to guarantee the needs of farmers and the overall survival of the people in the ecosystem concerned at all times. The purpose of this study was to analyze the sustainability of transmigrant farming and the factors that influence the sustainability of transmigrant farming. The study was conducted from May 2016 to January 2017. The population included 3,537 transmigrant households. The sample size in this study was determined by using the Slovin formula. The number of samples was 359 respondents, which was obtained through Stratified random sampling. The research data consisted of primary data and secondary data. The primary data were obtained through structured interviews, in-depth interviews, and observations in the field. The results of the study showed that the condition of the sustainability of transmigrant farming in the regencies of Banyuasin and Ogan Ilir was in the low category. The factors influencing the sustainability of transmigrant farming were the independence of the transmigrants in farming and the support of the socio-cultural environment.
\end{abstract}

Keywords: Farming sustainability, Transmigrants, Transmigration

\section{INTRODUCTION}

Transmigration development is an effort to integrate human resources (HR) and natural resources through population movement and spatial use. In line with the issue of development, an important concern is sustainable development which realizes current needs without decreasing the chances of future generations to meet their needs.

Sustainable farming is in line with the concept of sustainable development. Sustainable 


\section{International Journal of Social Science and Economic Research}

ISSN: $2455-8834$

Volume: 05, Issue: 01 "January 2020"

development is a concept that has been applied in various countries in the world. This concept seeks to provide optimal solutions to a variety of interests in the implementation of development. The concept of sustainable development was first introduced by the World Commission on Environment and Development (WCED) in 1987 with a report entitled "Our Common Future" (Kay and Alder 1999). The report includes the definition of sustainable development, which is the development that can meet current needs without limiting the opportunities of future generations to meet their needs. Through this understanding, Beller (1990) put forward the principle of "justice of fairness" which means that humans from different generations have duties and responsibilities to one another like being in one generation.

Sustainable development is oriented to three goal pillars: economic, social and ecological developments (Munasinghe 1993). The first pillar is economic development, which is oriented to growth, stability, and efficiency. The second pillar is social development which aims at poverty alleviation, identity recognition, and community empowerment. The third pillar is environmental development, which is oriented towards environmental improvement such as environmental sanitation, cleaner and lower emissions industries, and the preservation of natural resources.

The view of sustainable development put forward by Moffatt and Hanley (2001) is that sustainable development is an important part that must integrate the components of the resources, such as the economic component, socio-cultural component, and the environmental component in a harmonious and balanced manner. The harmonious and balanced utilization of resource components is intended to optimize the utilization of resources at the present time without reducing the opportunity and the fulfillment of the lives of future generations.

In line with community development and transmigration areas, through Law Number 29 Year 2009 concerning Transmigration, the importance of sustainable transmigration development has been explicitly stated. It was stated that to ensure the preservation of environmental functions in the transmigration area, resource management needs to be done wisely and mindfully by maintaining harmony in the local environmental functions so that business development can be sustainable. Considering the mandate of the law, all aspects of transmigration development activities should be based on the view of sustainable development.

In transmigration areas with farming patterns, the concept of sustainable transmigration development is also in line with the concept of sustainable agricultural development. Kuhnen (1992) states that in the concept of sustainability, agricultural development should be able to guarantee the needs of farmers and the overall survival of the people in the ecosystem concerned at all times.

Sustainable farming in transmigration areas is a target that should become an important concern 
in the community development and transmigration areas. The purpose of this study was to analyze the level of sustainability of transmigrant farming and examine the factors that influenced the sustainability level of farming.

\section{RESEARCH METHODS}

The type of research used was explanatory research that aimed to examine the relationship between research variables and test hypotheses that had been formulated previously. The study was conducted from May 2016 to January 2017. The study sites were in the regencies of Banyuasin and Ogan Ilir, South Sumatra Province, with consideration being the region with a large number of transmigrants in South Sumatra Province. The total population was 3,537 transmigrant households. The sample size in this study was determined using the Slovin formula. The number of samples was 359 respondents, using stratified random sampling, with strata: Transmigration Settlement, placement year, type of transmigration, and origin of transmigration (local and outside the province).

Data collection was done to get primary data and secondary data. The primary data were obtained through structured interviews, in-depth interviews, and observations in the field. The influence between variables was tested using SEM (Structural Equation Modeling).

\section{RESULTS AND DISCUSSION}

\subsection{Business Sustainability}

The sustainability aspects of transmigrant farming measured included business development, welfare, and the environment, all of which were in the low category. The percentages of each category are presented in Table 1.

Table 1: Distribution of respondents based on business sustainability in Banyuasin and Ogan Ilir in 2016

\begin{tabular}{|c|c|c|c|c|}
\hline \multirow{3}{*}{$\begin{array}{l}\text { Sub-Variables of } \\
\text { Business Sustainability }\end{array}$} & \multirow{3}{*}{ Category } & \multicolumn{2}{|c|}{ Regency } & \multirow[b]{2}{*}{$\begin{array}{c}\text { Total } \\
(\mathrm{n}=359)\end{array}$} \\
\hline & & $\begin{array}{c}\text { Banyuasin } \\
(\mathrm{n}=284)\end{array}$ & $\begin{array}{l}\text { Ogan Ilir } \\
\underline{(\mathrm{n}=75}\end{array}$ & \\
\hline & & $(\%)$ & $(\%)$ & $(\%)$ \\
\hline \multirow{5}{*}{$\begin{array}{l}\text { Business Development } \\
\text { Average score: } 42.1\end{array}$} & Decrease & 49.6 & 50.7 & 49.9 \\
\hline & Level off & 41.6 & 40.0 & 41.2 \\
\hline & Increase & 8.8 & 9.3 & 8.9 \\
\hline & amount & 100.0 & 100.0 & 100.0 \\
\hline & Decrease & 56.0 & 74.6 & 59.9 \\
\hline
\end{tabular}


International Journal of Social Science and Economic Research

ISSN: 2455-8834

Volume: 05, Issue: 01 "January 2020"

\begin{tabular}{lcrrr} 
Environmental Quality & Level off & 40.5 & 18.7 & 35.9 \\
Average score:55.9 & Increase & 3.5 & 6.7 & 4.2 \\
& amount & 100.0 & 100.0 & 100.0 \\
& Low & 50.4 & 37.3 & 47.6 \\
Welfare & Medium & 43.3 & 50.7 & 44.8 \\
Average score: 46.9 & High & 6.3 & 12.0 & 7.6 \\
& Amount & 100.0 & 100.0 & 100.0 \\
\hline
\end{tabular}

Note: Average score: Low $=0-50$, Medium $=51-75$, High $=76-100$

The low level of business sustainability was indicated by transmigrant farming activities which tended to be less developed in terms of the amount of production and the value of profits. Likewise, the quality of the environment, such as plant pest and water conditions, tended to be less conducive to plant growth. The welfare level of transmigrants also had not improved compared to the previous condition.

The main commodities planted by transmigrants are rubber and oil palm (Figure 1). Basically, rubber and oil palm farming has bright prospects, because the market demand for these commodities is high. One indicator is that all production produced by transmigrants is absorbed by the market. However, this opportunity cannot be fully utilized by transmigrants (Table 2). High product absorption by the market does not necessarily increase production and profitability due to many factors such as low land fertility, fluctuating water conditions, weak management and capital, limited access to superior seeds, weak bargaining position of transmigrants in marketing, and low ability of transmigrants to manage production.
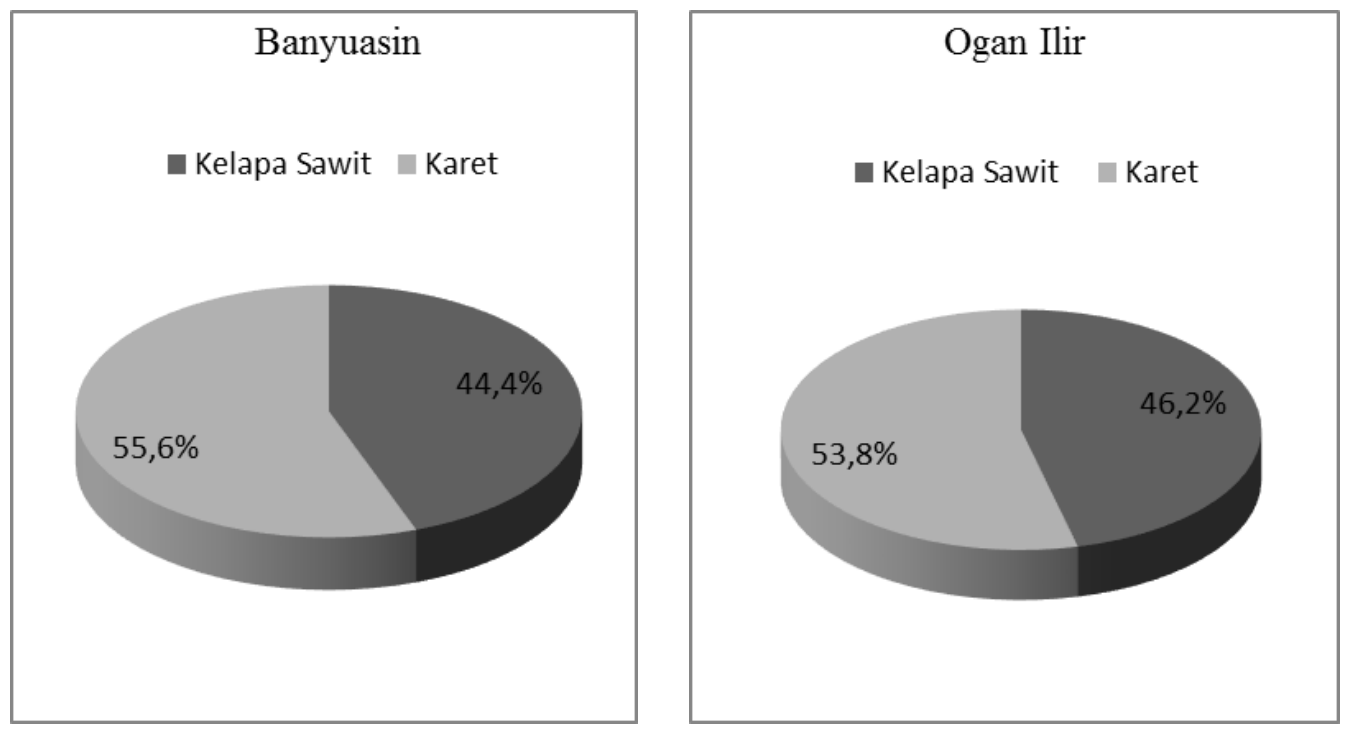

Figure 1: Percentage of land planted with oil palm and rubber 
International Journal of Social Science and Economic Research

ISSN: 2455-8834

Volume: 05, Issue: 01 "January 2020"

Source: results of research in 2017

An increase in production in a number of transmigrants also did not directly increase the profits, because the quality of the product could not be maintained, so that an optimal selling price could not be obtained. Commodity quality is influenced by the quality of production factors and the technical ability of transmigrants in managing the production process.

The average rubber production in transmigrant land only reached 15.6 percent of the ideal productivity of rubber per hectare in swamps, as well as the average production of oil palm on transmigrant land, only 64 percent of the ideal productivity of oil palm per hectare in swamps. Rubber and oil palm prices are very vulnerable to fluctuations following global market prices. The price of rubber at the time of the study at the transmigration site ranged from $\mathrm{Rp} 7,900$ to $\mathrm{Rp}$ 10,200 per $\mathrm{kg}$, while the price of oil palm ranged from $\mathrm{Rp} 900$ to $\mathrm{Rp} 1,100$ per $\mathrm{kg}$.

High productivity in carrying out farming activities is characterized by the ability to apply the principles of efficiency, generate a high level of profit, and be able to meet the needs of the production factors in a sustainable manner.

Table 2: Distribution of respondents based on business development in Banyuasin and Ogan Ilir in 2016

\begin{tabular}{|c|c|c|c|c|}
\hline \multirow{3}{*}{$\begin{array}{l}\text { Components of } \\
\text { Business Development }\end{array}$} & \multirow{3}{*}{ Condition } & \multicolumn{2}{|c|}{ Regencies } & \multirow{3}{*}{ 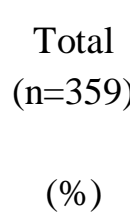 } \\
\hline & & $\begin{array}{c}\text { Banyuasin } \\
(\mathrm{n}=284)\end{array}$ & $\begin{array}{l}\text { Ogan Ilir } \\
\underline{(n=75}\end{array}$ & \\
\hline & & $(\%)$ & $(\%)$ & \\
\hline \multirow{4}{*}{$\begin{array}{l}\text { Production } \\
\text { Average score: } 47.5\end{array}$} & Turun & 49.6 & 50.7 & 49.9 \\
\hline & Level off & 27.8 & 26.7 & 27.6 \\
\hline & Increase & 22.5 & 22.7 & 22.6 \\
\hline & Amount & 100.0 & 100.0 & 100.0 \\
\hline \multirow{4}{*}{$\begin{array}{l}\text { Profit } \\
\text { Average score: } 36.6\end{array}$} & Turun & 55.3 & 56.0 & 55.4 \\
\hline & Level off & 35.9 & 34.7 & 35.7 \\
\hline & Increase & 8.8 & 9.3 & 8.9 \\
\hline & Amount & 100.0 & 100.0 & 100.0 \\
\hline
\end{tabular}

Note: Average score: Low $=0-50$, Medium $=51-75$, High $=76-100$

Source: results of research in 2017

Business sustainability from the environmental dimension showed that during the last three years the condition of soil fertility was low. In the meantime, and water conditions were also fluctuating, such as the nature of swamps (Table 3). The transmigration land in Ogan Ilir 
Regency is swampy swamp, and in the rainy season there is always an increase in ground water of $30 \mathrm{~cm}-1$ meter. This lasts about 3-4 months. The land in Banyuasin Regency is a tidal swamp land, and in the rainy season there is a tide with a height of about $20-30 \mathrm{~cm}$. This lasts for $2-5$ months every year. According to Ratmini (2014), the relatively long flooding conditions will affect the level of soil fertility both physically, chemically, and biologically.

In addition, from the aspect of disease pests, there was no change compared to the previous years, and the plant pests that attacked rubber and oil palm oil were the same as those in the previous years. The rubber diseases that mostly attacks plants at transmigration sites are white root fungus and deciduous leaves. The pests that attack are rats, monkeys, and pigs. The transmigrants hunted together to overcome pig pests.

Sustainability of the social aspects in terms of the level of welfare of transmigrant households, namely in terms of income, education, health, and physical condition of the house, showed that the majority of transmigrants in the two regencies (for the last three years) have not experienced an increase in welfare, but it tends to decline, instead (Table 4). This condition is related to the low development of the transmigration business, as explained earlier.

Table 3: Distribution of respondents based on environmental conditions in Banyuasin and Ogan Ilir in 2016

\begin{tabular}{|c|c|c|c|c|}
\hline \multirow{3}{*}{$\begin{array}{l}\text { Components of } \\
\text { Environmental Condition }\end{array}$} & \multirow{3}{*}{ Condition } & \multicolumn{2}{|c|}{ Regency } & \multirow{3}{*}{$\begin{array}{c}\begin{array}{c}\text { Total } \\
(\mathrm{n}=359)\end{array} \\
(\%)\end{array}$} \\
\hline & & $\begin{array}{c}\text { Banyuasin } \\
(\mathrm{n}=284)\end{array}$ & $\begin{array}{c}\text { Ogan Ilir } \\
(\mathrm{n}=75\end{array}$ & \\
\hline & & $(\%)$ & $(\%)$ & \\
\hline \multirow{5}{*}{$\begin{array}{l}\text { Soil Fertility } \\
\text { Average score: } 51.3\end{array}$} & $\begin{array}{l}\text { Significant } \\
\text { discrease }\end{array}$ & 16.2 & 38.7 & 20.9 \\
\hline & Decrease & 56.0 & 54.7 & 55.7 \\
\hline & Stable & 27.8 & 6.7 & 23.4 \\
\hline & amount & 100.0 & 100.0 & 100.0 \\
\hline & High & 19.7 & 13.3 & 18.4 \\
\hline \multirow{4}{*}{$\begin{array}{l}\text { Pest Attack } \\
\text { Average score: } 64.1\end{array}$} & Medium & 33.8 & 40.0 & 35.1 \\
\hline & Low & 46.7 & 46.7 & 46.5 \\
\hline & amount & 100.0 & 100.0 & 100.0 \\
\hline & High & 19.4 & 4.0 & 16.2 \\
\hline \multirow{4}{*}{$\begin{array}{l}\text { Plant Pest Attack } \\
\text { Average score: } 64.3\end{array}$} & Medium & 39.4 & 37.3 & 39.0 \\
\hline & Low & 41.2 & 58.7 & 44.8 \\
\hline & amount & 100.0 & 100.0 & 100.0 \\
\hline & $\begin{array}{c}\text { Very } \\
\text { Complicated }\end{array}$ & 9.9 & 18.7 & 11.7 \\
\hline
\end{tabular}


International Journal of Social Science and Economic Research

ISSN: 2455-8834

Volume: 05, Issue: 01 "January 2020"

\begin{tabular}{lcrrr} 
Flooding Condition & Complicated & & & \\
Average score: 44.2 & Complicated & 90.1 & 81.3 & 88.3 \\
& Stable & 0.0 & 0.0 & 0.0 \\
& Amount & 100.0 & 100.0 & 100.0 \\
\hline
\end{tabular}

Note: Average score: Low $=0-50$, Medium $=51-75$, High $=76-100$

Source: results of research in 2017

The main income of transmigrants came from the sale of rubber and oil palm commodities. Around 19 percent of transmigrants worked at oil palm mills near the transmigration settlement location. The wage of a worker of an oil palm factory in Ogan Ilir Regency was Rp 80,000 per day, while the wage of a worker of an oil palm factory in Banyuasin Regency was Rp 100,000 per day.

On average, in all transmigration sites schools have been available for transmigrant children from elementary school to junior high school. Senior high schools (SLTA) are found in 42 percent of transmigration locations. In other locations, if one wants to continue to high school, he or she has to travel a distance of $10-20 \mathrm{~km}$. There are public schools and some of them are private schools's.

The availability of puskesmas (including auxiliary puskesmas) already includes 71 percent of transmigration locations. In other locations, if you want to go to puskesmas, you have to cover a distance of $10-25 \mathrm{~km}$. Transmigrant access to puskesmas is quite affordable; however, the condition of the residential environment which is periodically always flooded and access to clean water is limited, making transmigrants and their families vulnerable to disease. This causes the health level of transmigrants to be low (Table 4).

Table 4: Distribution of respondents based on welfare in Banyuasin and Ogan Ilir in 2016

\begin{tabular}{|c|c|c|c|c|c|}
\hline \multirow{3}{*}{\multicolumn{2}{|c|}{$\begin{array}{l}\text { Components of } \\
\text { Welfare Level }\end{array}$}} & \multirow{3}{*}{ Condition } & \multicolumn{2}{|c|}{ Regency } & \multirow{3}{*}{$\begin{array}{c}\begin{array}{c}\text { Total } \\
(\mathrm{n}=359)\end{array} \\
(\%)\end{array}$} \\
\hline & & & $\begin{array}{c}\text { Banyuasin } \\
(\mathrm{n}=284)\end{array}$ & $\begin{array}{l}\text { Ogan Ilir } \\
\underline{(n=75}\end{array}$ & \\
\hline & & & $(\%)$ & $(\%)$ & \\
\hline \multirow{5}{*}{\multicolumn{2}{|c|}{$\begin{array}{l}\text { Income } \\
\text { Average score: }\end{array}$}} & Decrease & 30.6 & 26.7 & 29.8 \\
\hline & & Level off & 42.6 & 34.6 & 40.9 \\
\hline & & Increase & 26.8 & 38.7 & 29.3 \\
\hline & & Amount & 100.0 & 100.0 & 100.0 \\
\hline & & Low & 27.1 & 5.4 & 22.6 \\
\hline \multicolumn{2}{|l|}{ Education } & Medium & 19.7 & 25.3 & 20.9 \\
\hline Average score: & 67.0 & High & 53.2 & 69.3 & 56.5 \\
\hline
\end{tabular}


International Journal of Social Science and Economic Research

ISSN: 2455-8834

Volume: 05, Issue: 01 "January 2020"

\begin{tabular}{lcrrr} 
& Amount & 100.0 & 100.0 & 100.0 \\
& Low & 39.8 & 17.3 & 35.1 \\
Health & Medium & 39.8 & 44.0 & 40.7 \\
Average score: 44.6 & High & 20.4 & 38.7 & 24.2 \\
& Amount & 100.0 & 100.0 & 100.0 \\
House Condition & Low & 67.2 & 69.3 & 67.7 \\
Average score: 26.5 & Medium & 9.9 & 18.7 & 11.7 \\
& High & 22.9 & 12.0 & 20.6 \\
\hline & Amount & 100.0 & 100.0 & 100.0 \\
\hline
\end{tabular}

Note: Average score: Low $=0-50$, Medium $=51-75$, High $=76-100$

Source: results of research in 2017

Around 64 percent of the transmigrant houses in the study location are still original like the condition when they were first submitted; i.e. the ground floor or plank (houses on stilts) and plank walls. The rest have been renovated by building concrete floors and walls. Most (83 percent) of the transmigration sites have electricity for lighting in transmigrant houses. As for drinking water, the majority (86 percent) of the transmigrants still rely on rain water. Well water is only used for bathing and washing and cannot be used for drinking water because it tastes acidic. Suwarno et al. (1999) states that one of the characteristics of settlements in wetlands, such as swamps, is the difficulty of meeting clean water needs. Clean water sources need to be sought from other places with a pipeline system.

\subsection{Factors That Influence Business Sustainability}

Business sustainability was at a low level, as previously explained. The factors that significantly affect business sustainability are such variables as the independence of transmigrants (Y2) and the socio- cultural environment (X4) (Figure 2). These factors provide a significant influence in ensuring business sustainability in such aspects as business development, environmental quality, and level of welfare.

Simultaneously, the effect of the above variables on the sustainability of the transmigrant farming was 0.73 (Table 5). This means that the independence of transmigrants and the support of the socio- cultural environment together affected the empowerment of transmigrants by 73 percent, while the rest is explained by other variables. 
International Journal of Social Science and Economic Research

ISSN: 2455-8834

Volume: 05, Issue: 01 "January 2020"

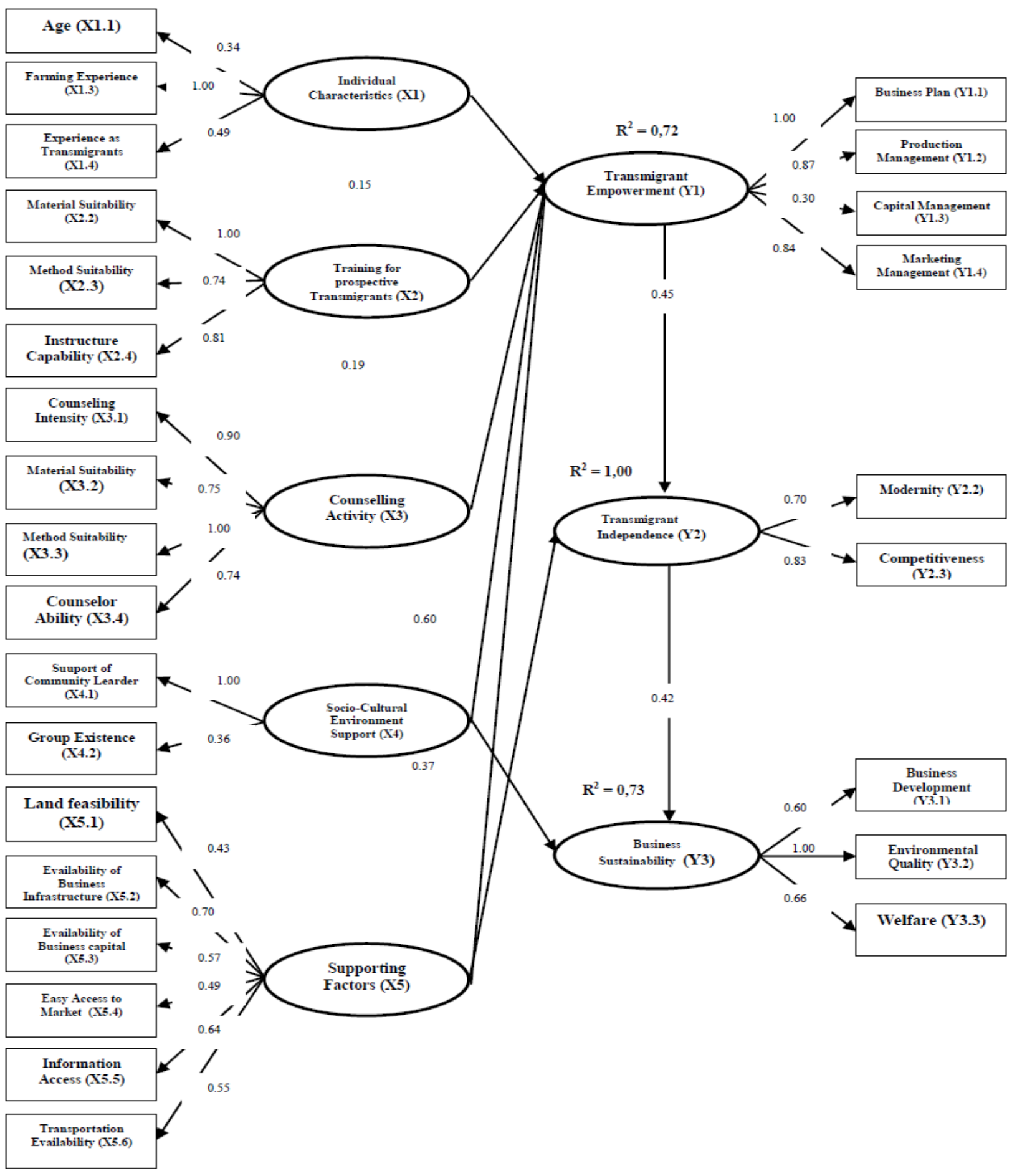

Figure 2: Factors that influence the business sustainability

Source: results of research in 2017 
The independence of transmigrants in farming had a significant effect on the sustainability of farming. The influence of transmigrant independence on the sustainability of farming was reflected by the indicators of competitiveness and modernity. This means that the independence of transmigrants in farming plays an important role in an effort to ensure sustainability in farming.

Socio-cultural environmental support factors, namely the support from community leaders and the existence of groups, contribute to supporting sustainability in farming. This can explain that the support of the community leaders and the existence of groups is very important to ensure sustainability in farming for transmigrants. This finding is in line with Soekartawi's (1993) statement, saying that the strength of the institutional system in rural areas also influences the development of agricultural commodity production.

Table 5: Coefficient values of the factors influencing the sustainability of transmigrant businesses in the 2016 study sites

\begin{tabular}{|c|c|c|c|c|c|c|c|}
\hline \multirow{3}{*}{$\begin{array}{l}\text { Independent } \\
\text { Variable }\end{array}$} & \multirow{3}{*}{$\begin{array}{l}\text { Dependent } \\
\text { Variable }\end{array}$} & \multicolumn{4}{|c|}{ Path Coefficient } & \multirow{3}{*}{$\begin{array}{l}\text { Value } t \\
\text { Counting }\end{array}$} & \multirow{3}{*}{$\mathrm{R}^{2}$} \\
\hline & & \multirow[t]{2}{*}{$\begin{array}{l}\text { Direct } \\
\text { Effect }\end{array}$} & \multicolumn{2}{|c|}{$\begin{array}{c}\text { In direct } \\
\text { Effect }\end{array}$} & \multirow[b]{2}{*}{ Total } & & \\
\hline & & & $\begin{array}{c}\text { Through } \\
\text { Y1 and } \\
\text { Y2 }\end{array}$ & $\begin{array}{l}\text { Through } \\
\text { Y2 }\end{array}$ & & & \\
\hline $\begin{array}{l}\text { Transmigrant } \\
\text { Independence }\end{array}$ & $\begin{array}{c}\text { Business } \\
\text { Sustainability }\end{array}$ & 0.42 & & & 0.42 & 2.01 & \\
\hline $\begin{array}{l}\text { Support of } \\
\text { Socio-culture } \\
\text { Environment }\end{array}$ & & 0.37 & & & 0.37 & 11.19 & 0.73 \\
\hline $\begin{array}{l}\text { Supporting } \\
\text { Factor }\end{array}$ & & & 0.16 & 0.25 & 0.41 & 1.99 & \\
\hline
\end{tabular}

Source: results of research in 2017

Another factor, which indirectly influences the sustainability of transmigrants in farming is a supporting factor. These factors affect the sustainability of transmigrants in farming through their contribution to the level of empowerment and independence of transmigrants in farming. This means that the higher the factor contributes to increasing the empowerment and independence of transmigrants in farming, the more they will guarantee the sustainability of transmigrants in farming. The supporting factors in question are: land suitability, availability of facilities, 


\section{International Journal of Social Science and Economic Research}

ISSN: $2455-8834$

Volume: 05, Issue: 01 "January 2020"

availability of capital, easy access to markets, access to information, and availability of transportation.

\subsection{The Effect of the Transmigrant Independence on Business Sustainability}

The influence of the transmigrant independence on business sustainability was reflected by such indicators as competitiveness and modernity. The competitiveness indicator was the strongest indicator $(\lambda=0.83)$, reflecting the transmigrant independence variables, followed by the modern indicators $(\lambda=0.70)$. Business sustainability was in the low category in all aspects, such as environmental quality, welfare, and business development. The low level of business sustainability was significantly affected by the independence of transmigrants. Therefore, to ensure the sustainability of business activities, it is necessary to develop the independence of transmigrants in farming.

The ability to apply innovations from other parties and to invent their own innovations and the ability to maintain product quality are among the indicators of independence in farming. In order to increase the ability of transmigrants to manage innovation, transmigrants need access to knowledge and information on various topics, such as: (1) the findings of the latest research from various disciplines; (2) farm management and production technology; (3) experience of other farmers; (4) the current situation and development that might occur in the market of inputs and production results; and (5) government policies. According to Subejo (2009), the information need for farmers should not only increase production but adjust to global issues. Farmers need to be introduced to innovations, such as: farming techniques that are environmentally friendly or production facilities that have high adaptability to climate shocks.

The condition of the quality level of agricultural output is largely determined by the technical ability of transmigrants. It is necessary to develop the ability of transmigrants (through training and counseling) to ensure product quality that is in accordance with the needs and expectations of customers.

\subsection{Effects of Socio-Cultural Environmental Support on Business Sustainability}

The influence of socio-cultural environmental support on business sustainability was reflected by such indicators as support of community leaders and the existence of groups. The indicators of support from community leaders were the strongest indicators $(\lambda=1.00)$, reflecting the sociocultural environment support variables, followed by indicators of the existence of groups $(\lambda=$ $0.36)$.

Business sustainability was in the low category, as explained earlier. The low level of business 
International Journal of Social Science and Economic Research

ISSN: $2455-8834$

Volume: 05, Issue: 01 "January 2020"

sustainability was significantly affected by the support of the socio-cultural environment (support of community leaders and the existence of groups). In this regard, to ensure the sustainability of business activities, it is necessary to increase the role of community leaders and strengthen farmer groups.

Community leaders as representatives of transmigrant communities and farmer groups as transmigrant institutions can be optimized in various aspects, including bridging cooperation with related parties to provide scheduled and ongoing training access to transmigrants. This is in an effort to develop the technical and managerial skills of transmigrants in farming so that they are able to increase production of the highest quality that will have an effect on increasing income which in turn can improve the life quality of transmigrants. According to Ibrahim et al. 2014, community leaders have the potential as agents of development that support the creation of dynamic groups, and strong farmer groups will be able to encourage increased cooperation between individual groups and outsiders.

\section{CONCLUSION}

The sustainability condition of the transmigrant farmers' farming in the regencies of Banyuasin and Ogan Ilir was in the low category, both in terms of business development, welfare, and environmental aspects. The factors that caused the low sustainability of transmigrant farming business were: (a) the low independence of transmigrants in farming, in terms of modernity and competitiveness; and (b) the low support of the socio-cultural environment, including the low support of community leaders and the existence of groups.

\section{ACKNOWLEDGEMENTS}

Thanks to the Directorate of Resources for Science, Technology and Higher Education, Ministry of Research, Technology and Higher Education of the Republic of Indonesia, as a source of funding for this research.

\section{REFERENCES}

[1] Beller W. 1990. How to Sustain a Small Island. In Beller W, d'Ayala P, Hein P, editors. Sustainable Development and Environmental Management of Small Island. Paris: The Parthenon Publishing Group.

[2] Kay R, Alder, J. 1999. Coastal Planning and Management. Routledge: New York.

[3] Kuhnen F. 1992. Sustainability, Regional Development, and Marginal Locations. Applied Geographyand Development, vol. 39. 
[4] Moffatt I, Hanley N. 2001. Modelling sustainable development: systems dynamic and input-ouput approaches. Journal Environmental Modelling and Software. 16:545-557.

[5] Munasinghe M. 1993. Environmental Economics and Sustainable Development. Washington DC: The World Bank.

[6] Ratmini NPS. 2014. Potensi pengembangan rawa lebak sebagai lahan pertanian mendukung pencapaian lumbung pangan di Sumatera Selatan. Seminar Nasional Pemberdayaan Petani melalui Inovasi Teknologi Spesifik Lokasi; 2014 Jul 21; Yogyakarta, Indonesia.

[7] Soekartawi. 1993. Agribisnis: Teori dan Aplikasinya. Jakarta: Raja Grafindo Persada.

[8] Suwarno Y, Abadi K, Helmi, Muslimin U, Ibrahim A, Supriyanto. 1999. Pemukiman transmigrasi pola lahan basah di daerah Saemba-Walati Kabupaten Poso. Jurnal Globe. 1(1):69-75. 